\title{
11 Beta-Hydroxysteroid Dehydrogenase Type 2 Deficiency
}

National Cancer Institute

\section{Source}

National Cancer Institute. 11 Beta-Hydroxysteroid Dehydrogenase Type 2 Deficiency.

NCI Thesaurus. Code C131083.

Decreased activity of 11-beta-hydroxysteroid dehydrogenase type 2 , which catalyzes the conversion of cortisol to cortisone due to autosomal recessive deactivating mutation(s) in the HSD11B2 gene. Resultant elevated cortisol concentrations in the kidney activate the mineralocorticoid receptor, resulting in hypertension, hypokalemia, and hypernatremia. 